\title{
The Grand National Assembly of Turkey and its Architectural Representation as a Memory Space
}

\author{
By Nazlı Taraz ${ }^{*} \&$ Ebru Yllmaz ${ }^{\dagger}$
}

In 1937, a national architectural competition was held for the construction of the third assembly building of Turkey with a brief invitation text by saying "we need an assembly building which symbolizes the continuity of the monumental Republic of Turkey and which overlaps the contemporary architectural trends of our era in the $20^{\text {th }}$ century" (www.kultur.gov.tr). With the praises and emphasis on the monumentality and stability of the Republic, the competition text plainly declares the national presence of the country in the $20^{\text {th }}$ century stage and expecting architectural manifestation of modernity and durability of the Turkish nation in its fundamental administrative building. In this way, the ideological objectives and the nationalist goals embodied in an architectural space representing the independent and monumental existence of Turkey in its assembly building as the memory space of the Republic. From this perspective, this paper aims to handle the Grand National Assembly of Turkey as the official and architectural representation of Turkish national identity by focusing on its construction process beginning from the competition phase, its completion in 1961 and the symbolic details representing the longlived existence of the nation from the history onwards. In order to discuss the GNAT as the memory space of the Republic, discourse analysis will be used by intertwining the collective memory and national architecture discourses in the Early Republican Turkey. In this context, architectural written media such as periodicals, newspapers and articles on national architecture discourse in the Early Republican Period will be used in addition to the archival research on the last assembly of Turkey. In this way, the last and contemporary assembly building of Turkey will be studied as a physical representation of Turkish national identity construction process and its concretization within the national architectural understanding of the mid-20th century.

Keywords: Grand National Assembly of Turkey, Assembly buildings of Turkey, Memory Space, National Identity, Early Republican Period

\section{Introduction}

From the history onwards, the desire for the territorial dominance and national sovereignty resulted in destructive actions of states by ruining of city centers housing religious, historical or national symbols. In the recent memory of the world, the two world wars and contemporary regional attacks have unfortunately become traumatic phenomena addressed to the destruction and demolition of monuments as the long-lived storages of memory and the historical knowledge of a nation. With a brief glimpse on the recent past, the historical sites of Palmyra, Aleppo and Raqqa are amongst the most destroyed lands in the first quarter of the $21^{\text {st }}$ century with attacks to the religious and public cores of the cities. Previously,

${ }^{*}$ Research Assistant, İzmir Institute of Technology, Turkey .

${ }^{\dagger}$ Associate Professor, Izmir Institute of Technology, Turkey. 
the World War II resulted in a comprehensive destruction in European cities such as Berlin, Florence, Dresden and Aachen with regional attacks to the historical monuments date back to the ancient times of their national history.

At the beneath of these subversive activities, the historical sites and the urban monuments have intentionally chosen as physical symbols carrying the traces and memories of the long-lived existence of a society, city or a nation in a larger scale. In this way, the more historical structures -buildings, monuments, squares or statues- are destroyed, the more damage is caused in the memories of a land. By physically destroying the memory spaces of a nation, it is aimed to destroy the collective memories and historical milestones specific to a place which transforms a land into a homeland. Thus, alongside all the destructive and tragic consequences, the ongoing agenda raises awareness to reconsider our cultural values and national symbols in our country which are accepted as living-witnesses of the centuries old civilizations from the history onwards.

Unfortunately, in 2016, Turkey has also faced with a threatening regime attack which resulted in destructive activities in different regions of the country, especially in Ankara and Istanbul. Amongst all the destructions, Turkey was heavily wounded from its national core with more than one bombings to the Grand National Assembly. In this way, it is aimed to endanger Turkish national existence with destroying its one of the most important symbols in the urban context which was constructed as the national representation of the Turkish Republic in the first half of the $20^{\text {th }}$ century. On that occasion, these tragic events resulted in rethinking on nation and national memory concepts with a special emphasis on the Grand National Assembly as the living proof and living witness of the Republican memories of Turkish nation.

Looking back to the 1937, when a national architectural competition was held for the construction of the third assembly building of Turkey, the brief invitation text declared "we need an assembly building which symbolizes the continuity of the monumental Republic of Turkey and which overlaps the contemporary architectural trends of our era in the $20^{\text {th }}$ century." With the praises and emphasis on the monumentality and stability of the Republic, the competition text plainly reflects the national presence of the country in the $20^{\text {th }}$ century stage and expecting architectural manifestation of modernity and durability of the Turkish nation in its fundamental administrative building.

In this way, it is aimed to embody ideological objectives and the nationalist goals in an architectural space representing the independent and monumental existence of Turkey in its assembly building of the country. From this point of view, this paper aims to investigate the Grand National Assembly of Turkey (GNAT) as one of the memory spaces of the Turkish national identity which carries the memories of the Republic and its representation in the urban context from its architectural competition phase to the completion in 1961 by staying in use until today. 


\section{Concretization of Memorialize: Memory Spaces}

In order to provide a better understanding for memory space discussion on the last assembly building of Turkey, examining memory discourse from different perspectives is found precious to understand how memory and its collective formations can lead to the construction of a national identity specific to a society. Thus, this paper begins with discussing the spatial representations of collective memory which have risen especially after the term "memory spaces" introduced by the French philosopher Pierre Nora in the beginning of the $20^{\text {th }}$ century. Up to that time, Maurice Halbwachs and David Lowenthal became key-figures in collective memory discourse by making certain demarcations and classifications on memory and its recollection channels individually and collectively.

To start with the French philosopher Maurice Halbwachs' On Collective Memory, the author handles collective memory as a continually changing concept depending on individuals and reads "collective memory is not a given but rather a socially constructed notion" (Halbwachs, 1992). In this respect, Halbwachs proposes three ways for memory recollection. Firstly, memories are transferred within families and close friends while we are growing up in a society. In this way, secondly, society emerges as a powerful setting in feeding and organizing our memories in minds within the physical environments that events occurred. Lastly, memories recollected instinctively by individual him/herself (Halbwachs, 1992). Accordingly, these three different recollection ways are re-shaped and reorganized in accordance with societies and physical environments as spaces of memories.

In a parallel vein, in Past is a Foreign Country, historian David Lowenthal begins his argument by asking "how do we come to know about the past?" and classifies the sources of past knowledge as memory, history and relics (Lowenthal, 2005). Accordingly, "memory is inescapable and prima-facie indubitable; history is contingent and empirically testable" for Lowenthal (Lowenthal, 2005). Although the author makes a demarcation between memory and history, he also emphasizes that the boundary between these two sources blurs continually by reading "uncertain where memory ends and history begins, we often attribute to one what comes from the other, jumbling early memories together with stories later heard and read, much as oral narrative conflates recent recollections with tales immemorially told" (Lowenthal, 2005). As the third source of past knowledge, relics are handled as concrete mnemonic symbols of the past in natural forms or artefacts (Lowenthal, 2005). In this way, they come to the forefront as the physical representations and living-witnesses of the history and collective memories of societies. Thus, all kind of architectural remains, buildings or artefacts in the urban context become invaluable storages for memory which are successfully endured to the destructive effects of passing time.

In a parallel vein, in Memory and Architecture, art historian Eleni Bastea asserts that architecture is an important medium which concretizes humanitarian values within spaces and stages to live (Bastea, 2004). By discussing the spatialization of shared values and collective memory of a society, Bastea uses the term "memory's voice". Accordingly, memory becomes an active voice in shaping 
our current lives by carrying the traces of the past. On the grounds of these cumulating traces of our histories, collective memory of a society constitutes a continuous ground for identification, remembrance, recollection and memorialization (Bastea, 2004). Thus, architecture emerges as a physical shelter for these activities in the urban context by physically concretizing memories into living spaces and experiences through spaces, representations and symbols.

Handling architecture as physical artefacts for keeping memories of a society is firstly introduced with the term memory spaces in 1984 by the French philosopher Pierre Nora. Accordingly, Hafiza Mekanları (originally published in French, Les Lieux de Memoire, 1984) Nora handles certain architectural components as memory storages of a nation which are concretized physically in the urban context by representing specific meanings or shared values in societies. From this point of view, Nora mentions archives, museums, mausoleums and national celebration spaces and buildings as memory spaces which are intentionally constructed artefacts for declaring and propagating revolutionary circumstances in cities (Nora, 2006).

Focusing on the memory and its collective formations, Nora emphasizes that collective memory is a convertible concept that leads to the construction of national identity in a society (Nora, 2006). In this respect, memory is handled as a "framework" for nations which can evaluate in accordance with its use in certain strategies such as national connotations, constructions or commemorations and celebrations for different purposes (Nora, 2006).

Accordingly, nation and its national identity become observable and representable notions are concretized in architecture through spatial organizations and their functional uses in certain intentions. In this way, memory spaces act as "laboratories" where the memorization is re-produced, re-formed and re-presented in specific places and in specific procedures (Nora, 2006). Thus, memory spaces are intentional constructions in the urban context to escape from the traces of a former society by declaring and propagating new characteristics of a new nation. By calling these construction activities as "reification of memory", Nora emphasizes that architecture emerges as an active actor in the spatialization of collective memory and its national formations in societies (Nora, 2006).

\section{Memory Spaces of Turkish National Identity: National Architecture Discourse in Turkey}

To piece together the different perspectives of Halbwachs, Lowenthal and Bastea, Nora's memory space discussion emerges as a significant unifier by evaluating the symbolic role of architecture in memorialization through physical spaces and their collective representations for nations. Thus, in this paper, the representational role of architecture in national connotations is specifically discussed upon the national architecture discourse of Turkey in the first half of the $20^{\text {th }}$ century. From this perspective, the First and Second National Movements of Turkey are investigated and the Grand National Assembly is handled as one of the most important memory spaces of the Republic. 
The transformation process of the Anatolia from being the lands of Ottoman monarchy to the Turkish Republic brought about radical changes in society from the beginning of the $20^{\text {th }}$ century. Within this framework, urban transformations were held by constructing new public buildings and institutions in order to declare and propagate new democratic Turkey to the world stage. Moreover, Ankara became the showcase of the Republic as the capital and leading modernization steps were initially paced through the new architectural context of the city. In line with this purpose, each step towards democracy physically embodied in architectural spaces in the capital by carrying special symbolic meanings which focused around the new republican national identity of the country.

In The Making of Modern Turkey, historian Feroz Ahmad elaborates the establishment of Republic and the construction of Turkish identity via the political and historical context of Turkey and emphasizes that Turkey is not a re-built version of the Ottoman Empire but a completely constructed new country of the Kemalists (Ahmad, 1993). In order to propagate the construction of the new identity, Young Turks were active in every field of the political and cultural context by advocating the idea that the former monarchy of the Ottoman Empire had to be abolished for the establishment of a "secular republic" (Ahmad, 1993). Similarly, Ayşe Kadıoğlu mentions Young Turks as the leading group for the new Turkishness ideal with the leadership of Ziya Gökalp by proposing the national identity and cultural structure of the Turkish nation had to be directly arisen from the "Turkish folk culture."

On the one hand, Gökalp outlines "civilization" as a progress which can be learned from the West, on the other hand, the "culture" and "identity" had to be strictly connected to the own folk of the nation itself (Kadığlu, 1997). In a parallel vein, in Modernizm ve Ulusun İşası (originally published in English Modernism and Nation Building: Turkish Architectural Culture in the Early Republic, 2001), architectural historian Sibel Bozdoğan focuses on the late 1930s when the Republican People's Party (RPP), as the party in power, declared a new understanding of history which rejects the Ottoman past and insists on creating a new "Turkishness" with its own national history (Bozdoğan, 2012).

Thus, in order to construct a new national identity, the RPP, Young Turks and intellectuals aimed to ground a new Turkish identity on a Turkish past which was separated from those of the Ottoman. Following the new reformist Turkish manner, nationalist movements were accelerated with a search for a national history, identity and its architecture as physical representations of the nationalist goals in the urban context. In this way, the modern architecture became an instrument which creates its own architectural language by smybolizing the new national identity of the country (Bozdoğan, 2012). A new national memory and its identity were produced via the modern public buildings especially in governmental offices, party buildings, post offices, museums, national libraries and archives as concrete symbols of the newly constructed Turkish Republic. Also, commemoration ceremonies, monuments and statues of succesful political figures of Turkey became important tools for constructing and symbolizing the new national identity and its national memory. 
In her dissertation "Making a National Architecture: Architecture and the Nation-state in Early Republican Turkey" (1998), architect and architectural historian Elvan Ergut comprehensively handles the conceptualization of national architecture by discussing the nation-building as a process instead of an end product, which can be represented through architecture. Mainly criticizing the general attempts to formulate the national architecture and nation-building as stable concepts which the latter was represented by the former, Ergut emphasizes that nationalism as a process "creates, invents, imagines, and construct nations" (Ergut, 1998). By placing nation-building process at the center, Ergut establishes correlational links between cultural, social, political and economic contexts with the national architecture. Thus, the architectural products are handled as meaningful entities which are produced and at the same time, produce the national representations in the urban context (Ergut, 1998).

On the one hand, Ergut highlights the idea that nation-building and its architectural representations are synchronous and interacting notions, in Cumhuriyet Dönemi Türk Mimarisi (Turkish Architecture in the Republican Period, 1996), art historian Metin Sözen handles architecture as a product of changing contexts and establishes his nationalism discussion on the remarked phases of architectural evolution of Turkey in the first half of the $20^{\text {th }}$ century. Handling architecture as the products of the national identity construction, Sözen looks backwards and begins his national identity discussion by marking the Second Constitutional Era (SCE) in 1908 and the First National Style as the beginning of the nationalism movements in architecture. During the following decade of the SCE, Sözen mentions increasing Turkism idea which was tried to be integrated all social and cultural networks of the country (Sözen, 1996). On the one hand, a search for a new national attitude was continuing by the Turkish architects, on the other hand, there was a remarkable tendency to re-interpret Ottoman details within the name of the First National Style (Sözen, 1996).

In a similar way, architectural historian İnci Aslanoğlu evaluates architecture in Turkey as an active part of changing contexts which lead a new understanding towards Turkish nationalism by advocating the idea that "architecture is not an isolated entity in itself" (Aslanoğlu, 2010). Accordingly, by focusing on the changing political, socio-cultural and economic contexts of Turkey, Aslanoğlu constructs her discussion on the changing architectural manner of the country in two main historical periods in 1920s and 1930s. Although the circumstances are highly different in these periods, both have similar underlying reasons in declaration and propagation of the new Turkish national identity. On the one hand, the author defines 1920s as "the years of shortage" when the destructive effects of the war were tried to be healed and Ankara was re-constructed as the new capital of the Republic; the 1930s is defined as a period when the new architectural attempts were tried in public and private constructions (Aslanoğlu, 2010).

In 1920s, Aslanoğlu's first classification corresponds to the First National Style in Turkey when the "history-based" architectural manner is used to declare newly introduced nationalism attitude in the built environment (Aslanoğlu, 2010). Accordingly in the First National Style, the Ottoman revivalism is highly used to provide a connection with the historical background of the country and at the same 
time, to represent the uniqueness of the democratic republican understanding in monumental scales (Aslanoğlu, 2010). In a parallel vein with Aslanoğlu, Bozdoğan handles this period as the first steps towards a new architectural language and construction techniques in Turkey beginning with the Ottoman revivalism (Bozdoğan, 2012). On the one hand, the architectural products of the First National Style had the characteristics of Ottoman architecture, on the other hand, new design principles and the use of new construction materials were combined in a modern way.

Ideologically and politically determined principles of the First National Style were applied mostly in Ankara as the capital of "the new Turkish nation." As the first building of the style, the office building of the Committee of Union and Progress (Ittihat ve Terakki Cemiyeti), was built in Ankara in 1917 by Salim and Hasip Bey and then, the building was converted into the first national assembly of Turkey in 1920 as the concrete declaration of the transition from monarchy to democracy at the heart of the capital city (Bozdoğan, 2012). By housing the rapturous periods of the newly establishing Republic, this building became the core of the nationalist movements in the first quarter of the $20^{\text {th }}$ century.

In 1924, the administrative core was moved to the Second Assembly of Turkey, which was designed as the office building of the Republican People's Party by the architect Vedat Tek. Then, the first national assembly was began to serve as the Headquarter of the Republican People's Party building and law school up to its conversion into the Museum of Grand National Assembly in 1961 and the Independence War Museum in 1981.

From its opening in 1924 to the completion of contemporary assembly building of Turkey in 1961, the second assembly of the Republic became a concrete representation of Ataturk's principles and reforms, contemporary trends and nationalist movements. In the opening ceremony of the second national assembly, a striking opening speech was made by reading “... the new Turkey state is a people's state, but in the past, it was a state of one person... The grand thought movements which rescued the certain societies from captivity and liberated them are the archenemies of people who relied upon obsolete institutions and decayed regimes... The new Turkey state is the representation of this grand idea which dominates the world and a realized example of its actualization" (www.tbmm.gov.tr).

In this way, the nationalist manner of the time and its architectural symbolization in the urban context was publicly declared and propagated upon the second assembly building of the country. After to the opening of the third and contemporary assembly in 1961, the second was converted into the Museum of Republic in 1979, which has been stayed in use until today.

At the end of the 1920s, counter-views on the First National Style began to emerge upon the idea that the Ottoman revivalism was an outdated fashion which had to be abandoned in order to reach a modern architectural under-standing based on functional and rational approach (Bozdoğan, 2012). These rejections increased rapidly and in 1930s and, the First National Style was abandoned with a counter movement: the New Architecture. In order to create a new understanding in architectural language representing the Turkish nation, the local architects 
advocated the idea that the ongoing Ottoman-revivalism has to come a halt and a new modern, functional and rational architecture is needed to propagate Turkishness on the world stage.

Overlapping with Bozdoğan, Aslanoğlu classifies this period beginning with the International Style, to the Neo-Classical Style and finally ends with the Second National Style (Aslanoğlu, 2010). Accordingly, the main reason for this threestaged progress, Aslanoğlu mentions the co-working of the foreign and local architects to construct national architecture of the Republic (Aslanoğlu, 2010). On the one hand, the foreign architects, such as Giulio Mongeri, Ernst Egli, Bruno Taut and Martin Elsaesser, etc. preferred the monumental architectural style to propagate nationalism, the Turkish architects used western-focused rational and functional attitude in architecture. In this way, monumental, symmetrical and highly decorative attitudes of the First National Style was replaced by purist, simple and functional architectural manner in the International Style (Aslanoğlu, 2010). As Aslanoğlu stresses, the International Style was realized with concrete skeleton systems, plain roofs, cubical masses, asymmetrical volumes which were organized with the form-function relationship (Aslanoğlu, 2010). Especially in this period, Sedad Hakk1 Eldem contributes greatly to the International Syle in Turkey with residential and storage buildings (Bayan Firdevs Evi and SATIE Storage) in İstanbul (Aslanoğlu, 2010).

Secondly, the Neo-Classical Style became another main architectural tendency in the 1930s. At that time, not only Turkey but also the other countries in the world, such as France and Germany, widely used the monumental representation of the Neo-Classical style in their architectural products to declare their states' independence and freedom via the gloriousness of the built environment. Thus, the majority of the monumental Neo-Classical buildings were the products of the foreign architects who were invited to participate in the establishment of the new architectural language of Turkey, while the functional International Style was generally preferred by the Turkish architects (Aslanoğlu, 2010). However, Şekip Akalın's Ankara Station, Bedri Uçar's Turkish State Railways Building and Sedad Hakk1 Eldem's Inhisar General Directorate Building are amongst the leading examples of monumental Neo-Classical understanding of the time designed by the Turkish architects (Aslanoğlu, 2010).

As a result of the major domination of the foreign professionals in the Turkish national arhitecture, the Second National Style was emerged as a common reaction to the activities of the foreigners in the late 1930s. Aslanoğlu explains this phase of the architectural search of Turkey as an escape from the foreign influences in national architecture and the will to prove the sufficiency of Turkish architects to declare new Turkish identity in their own architectural products (Aslanoğlu, 2010). Although the architectural manner is generally focused on the products of Turkish architects, the existing circumstances on the construction and design techniques resulted in involuntary collaboration with foreigners. Leadingly, the Austrian architect Clemens Holzmeister became one of the most important architects of the Second National Style in Turkey by designing the ministry buildings of Defense, Interior, Public Works and Presidency of the Judicial Council in Ankara, additionally to his public building designs in the city. 
At this time, the most popular architectural publications of the era - journals of Mimar, Mimarlik and Arkitekt - become significant indicators of ongoing discontent on "foreign architect admiration" through the articles of well-known Turkish architects and planners. In his detailed book on the foreign architects problem in Turkey, architect Gürhan Tümer compares positive and negative reactions on the collaborations with foreigners in the Republican period by analyzing the articles of the time. While a group of administrators, architects, planners and media professions were supporting the productive atmosphere of the co-operations with foreign architects, a remarkable group rejected the dominant influence of foreigners in the built environment. Basically regarding the cultural concerns in discussion, the opposite group advocates the idea that a national architecture of a country could only be properly realized by its own citizens (Tümer, 1998).

As amongst the vigorous advocators of Turkish architects in national discourse, architect Abidin Mortaş expresses his discontent by saying "we are not engaging in a mere nationalism demagoguery. We are justifiably advocating that it is necessary to be proud of the products of a well-educated Turkish group, instead of blindly and uncomprehendingly appreciating all foreign works in this country..." (Tümer, 1998). Similarly, another well-known architect of the time, Şevki Balmumcu argues the journalist Falih Rufkı Atay's positive opinions on the foreign collaborations by writing "we are inviting Falih Rıfkı Atay for making a proper analysis and observation on the situation we are in... Then, of course, he will understand the circumstances and write again..." (Tümer, 1998).

In brief, the comprehensively changing political and socio-cultural context of Turkey in the $20^{\text {th }}$ century physically manifested itself in the built environment which was shaped under the effect of multiple perspectives on modernity, nationality and its architectural representations in the urban context. Especially Ankara became one of the most important stages of the new nationalist attitude in the country by representing the new Republican identity of Turkey as the capital city. Long-standing searches for the construction and representation of the Turkish nationalism concretized in architectural spaces of the capital especially beginning with the First National Style in the early 1920s. Then, the architectural manner evolved and developed with the followed-up styles with the participation of important foreign architects of the time. In 1930s, the Second National Style emerged as the representation of a more settled and embraced nationalist attitude in the built environment with its own structural language and representative symbolism.

In comparison with the transition atmosphere of the 1920s, the more established and stable nationalist manner of Turkey in the 1930s needed a new administrative core which carries all the modern and reformist symbols of the Republican identities. Thus, the government decided to declare, propagate and represent its grandeur national existence and stability via its official administrative building by symbolizing the established democratic regime and its citizens as the primary actors of the Republic. Within this purpose, an international design competition was held in 1937 with a brief invitation text declaring "we need an assembly building which symbolizes the continuity of the monumental Republic 
of Turkey and which overlaps the contemporary architectural trends of our era in the $20^{\text {th }}$ century" (www.kultur.gov.tr).

\section{Representation of a Nation in the Urban Context: The GNAT and the Ministries Quarter}

As the product of a foreign architect in the Second National Style, the Grand National Assembly of Turkey (GNAT) was designed by the Austrian architect Clemens Holzmeister in 1938 and, after its completion in 1961, the building has stayed in use up today. In addition to the invitation text, the competition committee declared the necessities for the assembly as "the competition aims to construct a monumental representation of the Turkish Republic in the $20^{\text {th }}$ century stage which has to symbolize the perfect and pure manner in architectural style, in addition to its grand and detailed programme" (Yartm Asırlık Meclis Binasl: 51. Yll, 2012). In contrast to the first two assemblies of Turkey, the GNAT became the first administration core of the country which is constructed as an assembly from the beginning (To make it clear, the first assembly was formerly used as the office buliding of the Committee of Union and Progress and similarly, the second was used as the office of the Republican People's Party before its use as the second assembly of Turkey.). In the January of 1937, the international competition was declared with the decisions of the Chairmanship Council (Riyaset Divant) and GNAT Presidency Council - Competition Commission (TBMM Başkanlık Divanı Yarışma Komisyonu) with the jury members, W.M. Dudok from Holland, I. Tengbom from Sweden and H. Robertson from England (Yarım Asırlı Meclis Binast: 51. Yll, 2012).

In the January of 1938 (see Figure 1 for the announcemnet of the winning project), Holzmeister's project got the first place and the construction was began in 1939 up to the the obligatory break in 1941 when the World War II affected all the countries with the limited work force due to the large-scale economic and political crisis (Yartm Asırlık Meclis Binast: 51. Yll, 2012). After a year, construction began again with a detailed division of labour consisted of Turkish, English and Swedish architects, engineers and contractors. Additionally, the architect Ziya Payzin, who was the student of Holzmeister at the time, was also charged with the detail drawings of the project (Yartm Astrlk Meclis Binast: 51. Yll, 2012). Then, in 1948, Payzin was fully tasked with the supervision and control of the project up to the completion. Before its opening as the assembly, the GNAT was firstly used for the meeting space of CENTO (The Central Treaty Organization) in 1957 and four years later, the building was officially opened as the last and contemporary assembly of Turkey (Yarım Astrlık Meclis Binast: 51. Yll, 2012).

By keeping in mind briefly the chronological history of the GNAT, it has also vital importance to understand the symbolic representation of the campus in the urban structure in a larger scale. As mentioned previously, the nationalist manner in the newly established Republic manifested itself in the built environment through architecture and its iconographic representations in the urban context, especially in the Ankara as the capital. In a parallel vein, the city has passed an 
overall re-construction process to become the new and modern core of the Turkish Republic, which comes into existence independently from the centuries old center of the country, İstanbul. Thus, within the frameworks of the new necessities of a Republican capital city, the urban scale re-organization of Ankara was firstly realized by the German architect Carl Christopher Lörcher in 1924.

Figure 1. Announcement of the Winning Project for the Grand National Assembly Complex-Ulus Newspaper, $23^{\text {rd }}$ February 1938

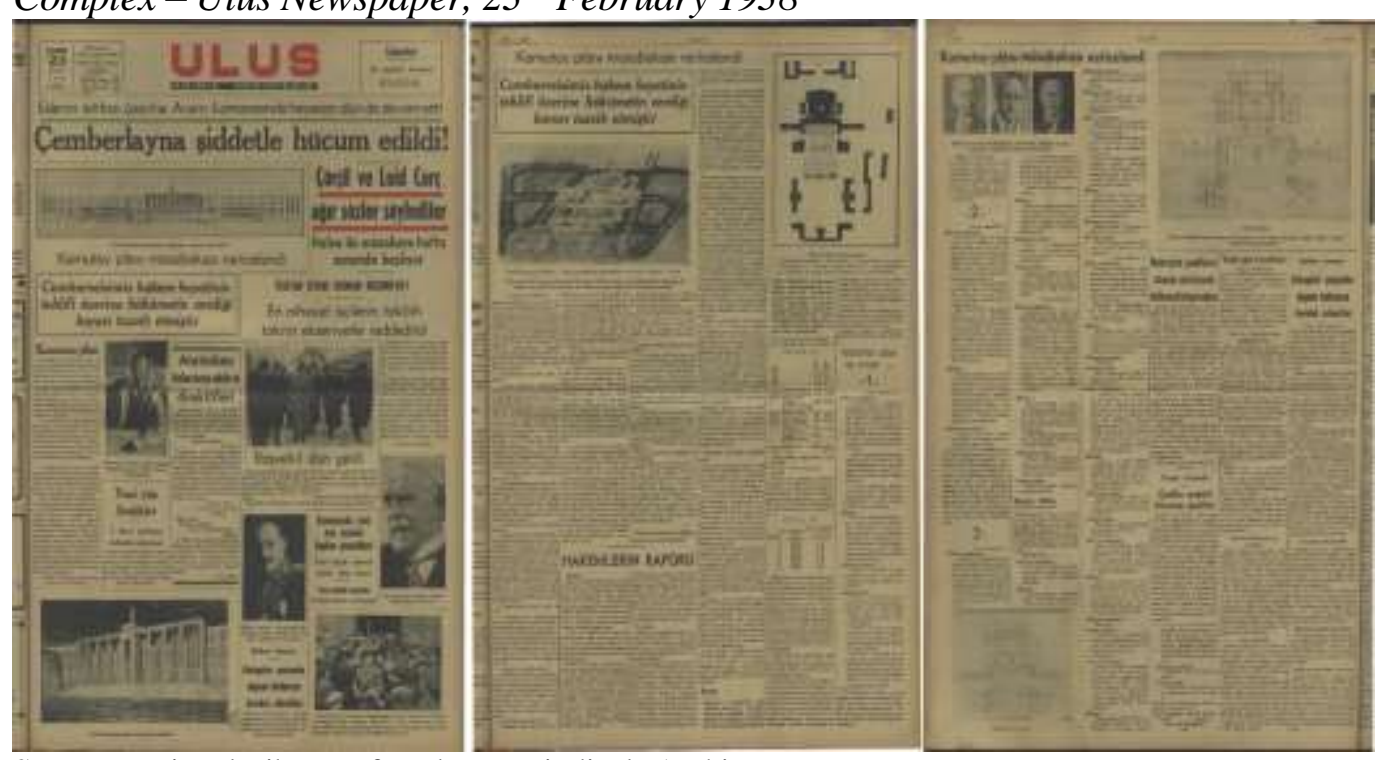

Source: National Library of Turkey, Periodicals Archive.

Basically, the Lörcher plan (Figure 2) divides the city into two main regions as the Old and New City which were organized according to the specific functional zones in the urban structure. In "Türkiye için Modern ve Planlı Bir Başkent Kurmak: Ankara 1920-1950" (Making a Modern and Planned Capital City for Turkey: Ankara 1920-1950), Cengizkan defines Old City of Lörcher as the accommodational areas for the fast growing population of Ankara, while the New City is privatized for the public and governmental needs of the capital (Cengizkan, 2018). In this respect, Çankaya neighborhood was firstly designed where the governmental buildings of the Republic are located around the public parks and squares accessed through wide boulevards (Cengizkan, 2018). In his another chapter in Clemens Holzmiester: An Architet at the Turn of the Era (2010), Cengizkan defines Çankaya region in detail with a special emphasis on the Ministries Quarter which was proposed in Lörcher's plan "with a wage-shaped site allotment" housing the ministry buildings, the Grand National Assembly Campus and a public park in the zone (Cengizkan,_2010).

In 1927, the proposed zones and the city planning decisions remained incapable for the needs and the three of well-known city planners of the era were invited to Ankara for a more developed city plan proper to the capital of the Turkish Republic. At this point, in Architecture, Power, and National Identity (1992), urban designer and planner Lawrence Vale describes Ankara as "the reconfiguration of the distribution of political, cultural and economic power in the 
new state" and thus, the capital needs a more stable and organized urban layout to be an innovative and modern representation of the Republic (Vale, 2008). Amongst the plans of Jansen, Jausseley and Brix, Jansen's proposal was approved with his Garden City concept consisted of a central green area with surrounding neighborhoods as educational, governmental, accommodational and working zones (Vale, 2008).

Figure 2. Lörcher Plan, 1924

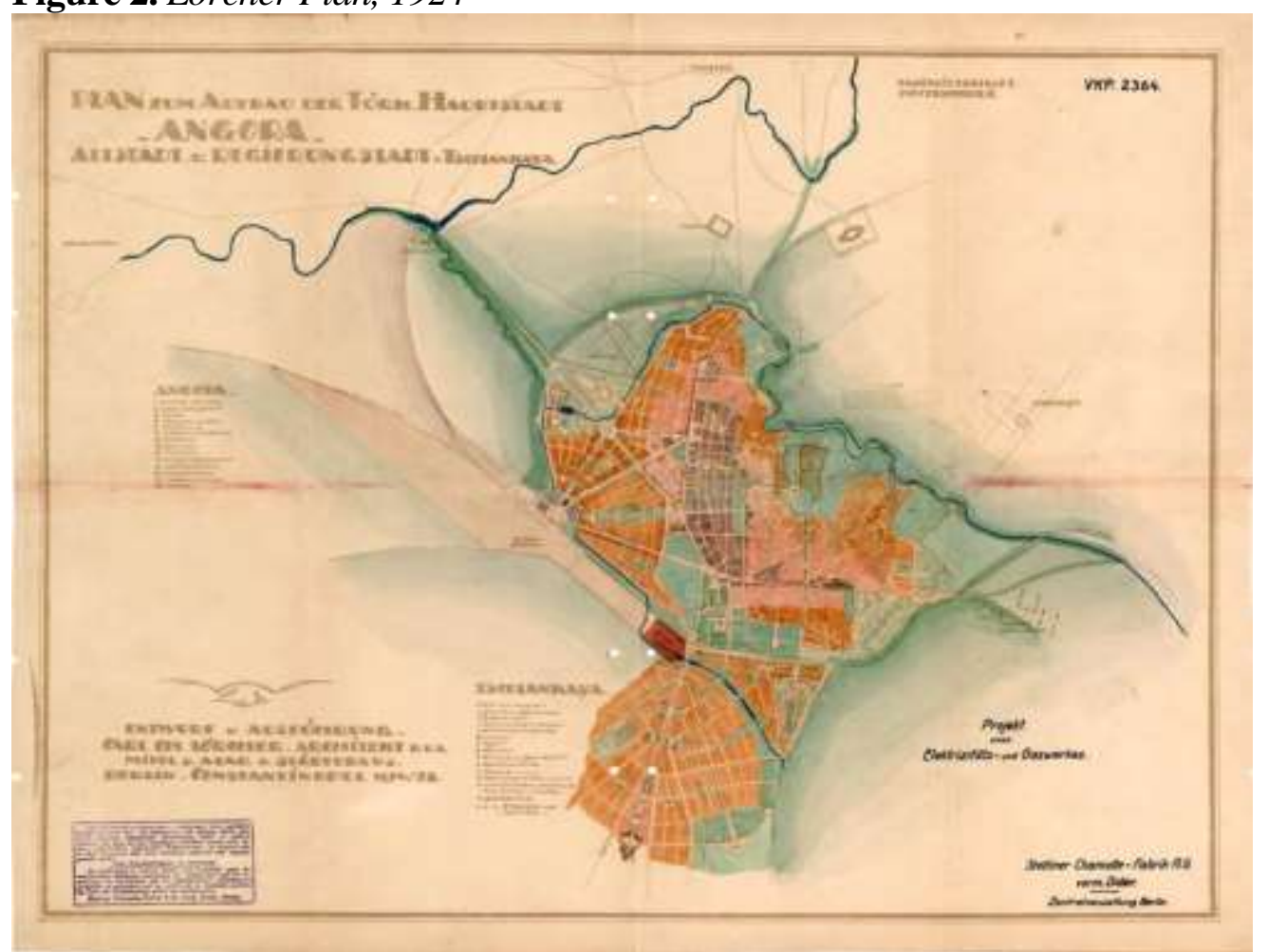

Source: http://www.goethe.de

Basically, the second city plan proposals were supposed to follow basic design principles of Lörcher's, regarding the zoning strategy with the preservation and development of the Ministries Quarter in Çankaya (Cengizkan, 2010). Importantly, as one of the striking representations of the Turkish Republic in the urban context, the main axis of the new city plan was called as the Atatürk Boulevard, who was the founder of the new country. As stated in the Presidency Senate publication of TBMM Kampüsünün Dünü-Bugünü-Yarını (1976), the Ministries Quarter formerly called as the Cumhuriyet Anttı (the Monument of Republic) by Mustafa Kemal Atatürk to symbolically represent the new Turkey with its Republican state buildings and the contemporary assembly building at the heart of the city (TBMM Kampüsünün Dünü-Bugünü-Yarını, 1976).

Accordingly, the future development of Ankara was determined toward south and the zones were re-organized with the new neighborhood proposals regarding their functions as education, accommodation or working areas (Cengizkan, 2018). As the administrational zone, the former proposal of Lörcher's triangular governmental area was preserved and Jansen collaborated with Holzmeister for 
construction and location of the state buildings (Cengizkan, 2010). Chronologically developed with the constructions of the ministries of National Defense, Interiors, Public Works, Economics and Agriculture, the administrational zone was organized towards the north (Figure 3), where the Grand National Assembly was located on the highest point of the area (Cengizkan, 2010).

Figure 3. Jansen Plan, 1927

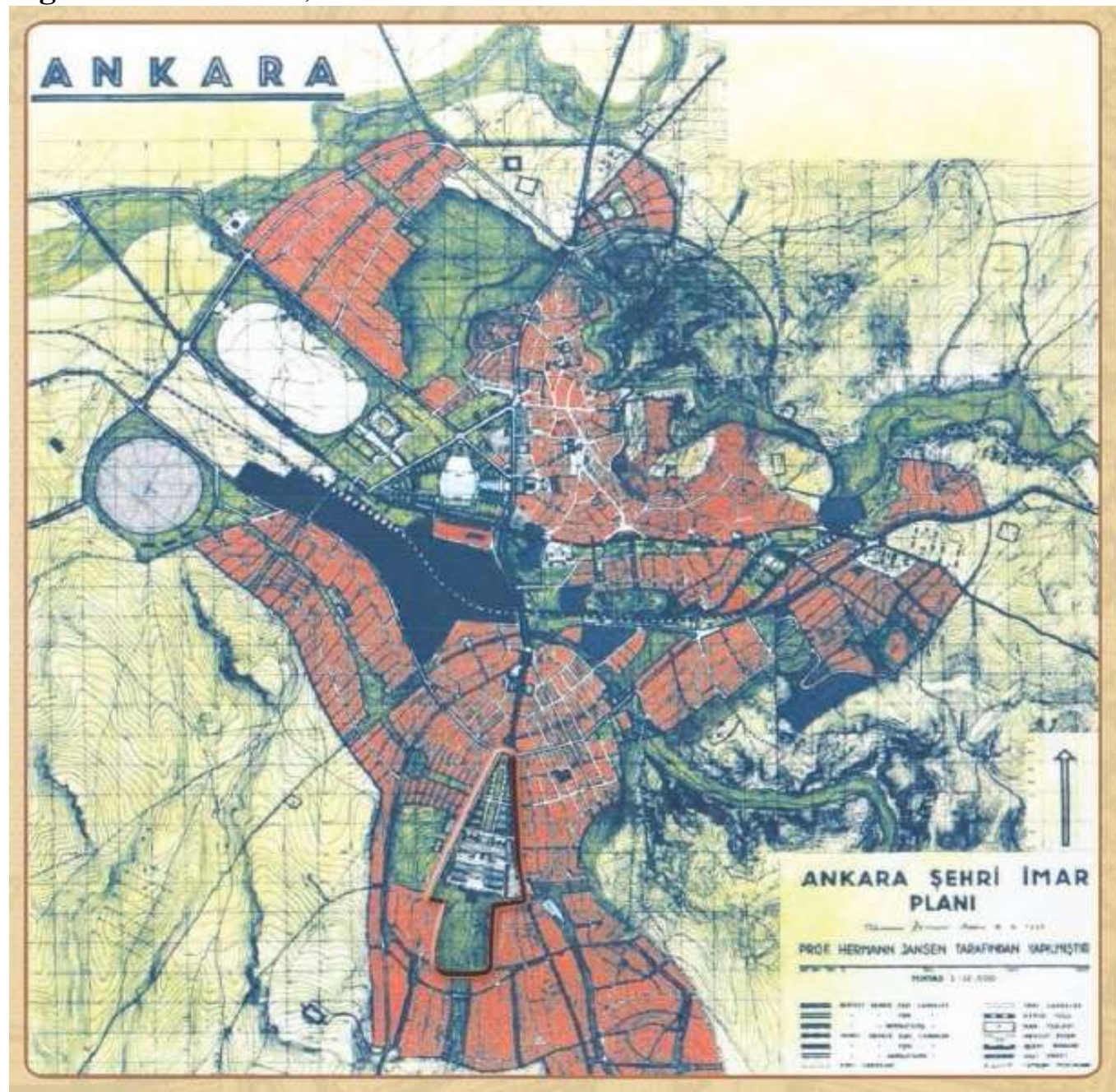

Source: Yarım Asırlık Meclis Binası: 51. Y11, 10.

Importantly in the new plan, the governmental zone needed to have a public area where the administratives and citizens could "meet" proper to the ideological basis of the democratic Republic. In this way, as Demirkol stated in her dissertation, the Güven Park and Güven Anıtı (Security Monument and the Security Monument) were located on the southern area of the zone to link the city physically and visually to the Grand National Assembly on the north through the Atatürk Boulevard as the main axis (Demirkol, 2009). Thus, the reliability and stability of the state is publicly declared at the beginning of its fundamental administrative axis which continues with the ministry buildings of the Republic (Demirkol, 2009). 
On the one hand, when the construction of the GNAT was completed in 1961, the building was ready for the administrative meetings and for functioning as a parliament building with its completed convention halls, offices, grand rooms and proper technical details such as heating-cooling or ventilation. However, the symbolic additions to represent democratic Turkish nation and its long-lasted history have to be physically declared in the GNAT. Thus, under the light of Holzmeister's project, the GNAT have various symbolic details in the building scale from the entrance to the lightenings and material decisions in structure. In this way, the urban scale symbolization of the campus was completed with the interior details in the GNAT proper to the new democratic regime of the long-lived Anatolia lands.

\section{Symbols of a Nation: Iconographic Details in the Grand National Assembly of Turkey}

Clearly, the GNAT leaves an iconographic mark in the urban context by locating at the highest point of the city and by surrounding new Republican state buildings and public parks in its immediate vicinity. From its design and construction phases to the official use as parliament building of the Turkish Republic in 1961, the GNAT imprinted on the memories as an achitectural representation of the new Turkish national identity by becoming a meeting point for Turkish people with their administrators through the physical and ideological symbols of the Republic.

When the new understanding of Turkey in the $20^{\text {th }}$ century was necessitated a new manner in political behavior of the state, naturally, the capital city is needed a new grandeur architectural representation of the Republic in the urban context to propagate and declare the durable and stable national character of the Turkish state. From this perspective, in her dissertation, Demirkol states that the GNAT campus was designed regarding certain design principles to increase the "readability and orientation of the crowds" in special meetings of the state proper to the political mind of a democratic regime (Demirkol, 2009). Thus, the space organization of the GNAT was designed around green areas, squares, courtyards, forecourts and wide meeting halls which would properly function as meeting areas for the upper statesmen, parliament members and public (Demirkol, 2009).

However, the wide courtyards of the assemby complex received public events only in certain times such as the sod-tuning ceremony in 1939 or the opening ceremony of the Atatürk Monument in 1981. In large part of the gatherings were realized by the political figures of the time and in this way, the GNAT courtyards were used actively not by public but by the statesmen, especially in inauguration ceremonies of political periods.

In this way, it is aimed to construct unity and solidarity of the Turkish nation around the shared values of people and their collective activities in special national connotations. The celebrations of national bairams and opening ceremonies of the government annually become significant unifying occasions in the Republic, which strengthens and consolidates the national identification and sense of 
belonging in masses through architecture. By placing architectural artefacts at the core of the collective occasions in societies as stages for the construction of national identity, this paper includes memory discussion by handling the GNAT as a significant memory space for the Turkish Republic. In this way, the iconographic remark of the GNAT in the collective memories of Turkish people is tried to understand by handling the building as an architectural artefact housing various symbolic details referring to the long-lived history of the Turkish states and its firm national shared values.

From this perspective, in Memory and Material Culture, Jones handles architecture as concretization of collective memory by evaluating them by being storages of "symbols" and "units of information" (Jones, 2007). Accordingly, not only artefacts but also all kind of materials from history onwards such as stone tablets to the photographs and computerized systems are accepted as memory storages (Jones, 2007). Focusing on the material culture and their relation with society, Jones places memorialization and recollection ways at the heart of his discussion by asking "how things help societies remember?" (Jones, 2007). Thus, all the materials as memory storages have implicit meanings immanently which become invaluable witnesses of history (Jones, 2007). Importantly, Jones emphasizes that the material culture of a society can not provide remembering by itself but can open the roads by preparing collective occasions to recollection through collectively shared experiences (Jones, 2007). In a parallel vein, the GNAT have various symbolic details in the inner and outer spaces of the assembly complex, which become active participators of the collective national ocassions and stages for the construction of a national imagery integral to the political core of the Republic.

Figure 4. Aerial Perspective of the GNAT Campus from the Sketches of Clemens Holzmeister

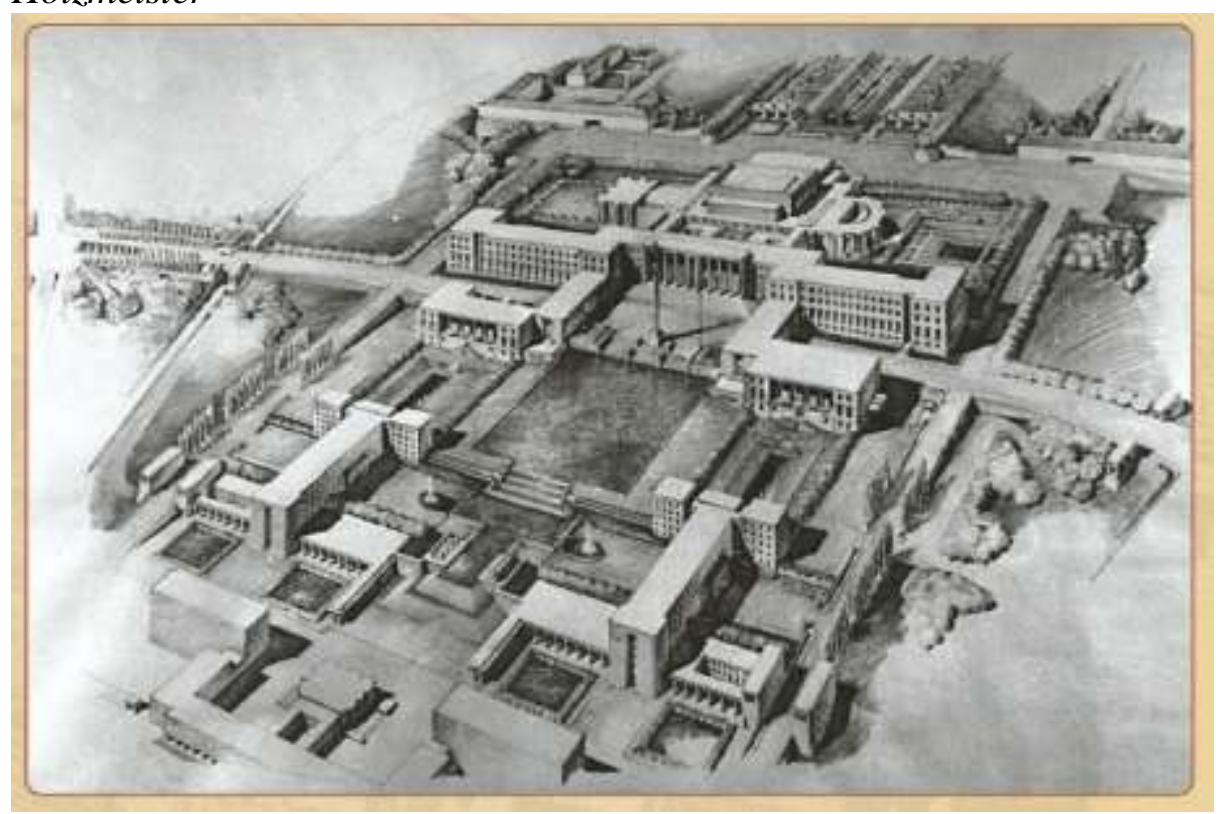

Source: Yarım Asırlık Meclis Binası: 51. Yı1, 17. 
Within this framework, the symbolic references in the GNAT can be divided into two main periods as dating back to the beginning of the 1960s and to the last years of the 1970s. Accordingly, the first phase overlaps with the opening years of the GNAT, which were produced according to the Holzmeister's original project and structural details (Figure 4). As stated in the competition text, the GNAT have to become an iconographic representation of the stable and durable existence of the Turkish Republic which draws its strength from the centuries old Turkish states in history.

Beginning from the outer space of the GNAT housing the opening ceremonies of the state and national bairam celebrations, the Turkish flag in the central point of the grand courtyard symbolizes the stability, sovereignty and invincibility of the Republic (Figure 5). Thus, this flag have never hauled down in any circumstances which struggles the country deeply (Yarım Asırlık Meclis Binast: 51. Yll, 2012). Then, the main entrance gate of the GNAT is realized from the Şeref Kapısı (The Honorary Gate), which have also symbolic details in its ornament. Accordingly, the wattling pattern of the door symbolizes the indivisible integrity of the Turkish Republic through the inseparable knitting. By carrying the star and the crescent as the symbols of the Turkish Republic, the Honorary Gate can only be used by the president of the Republic and the chairperson of the parliament (Yartm Astrlik Meclis Binast: 51. Yll , 2012). Additionally, the gates of the president and the chairperson differentiates in passing through the general convention hall of the GNAT. Here, the Damlalı / Salkım Kapı (The Drop / Bunch Door) is ornamented with sixteen drop figures to symbolize sixteen Turkish states in the history.

Figure 5. The Turkish Flag (uppermost), Honorary Gate (lower-left) and the Water Drop Door of the Grand National Assembly.

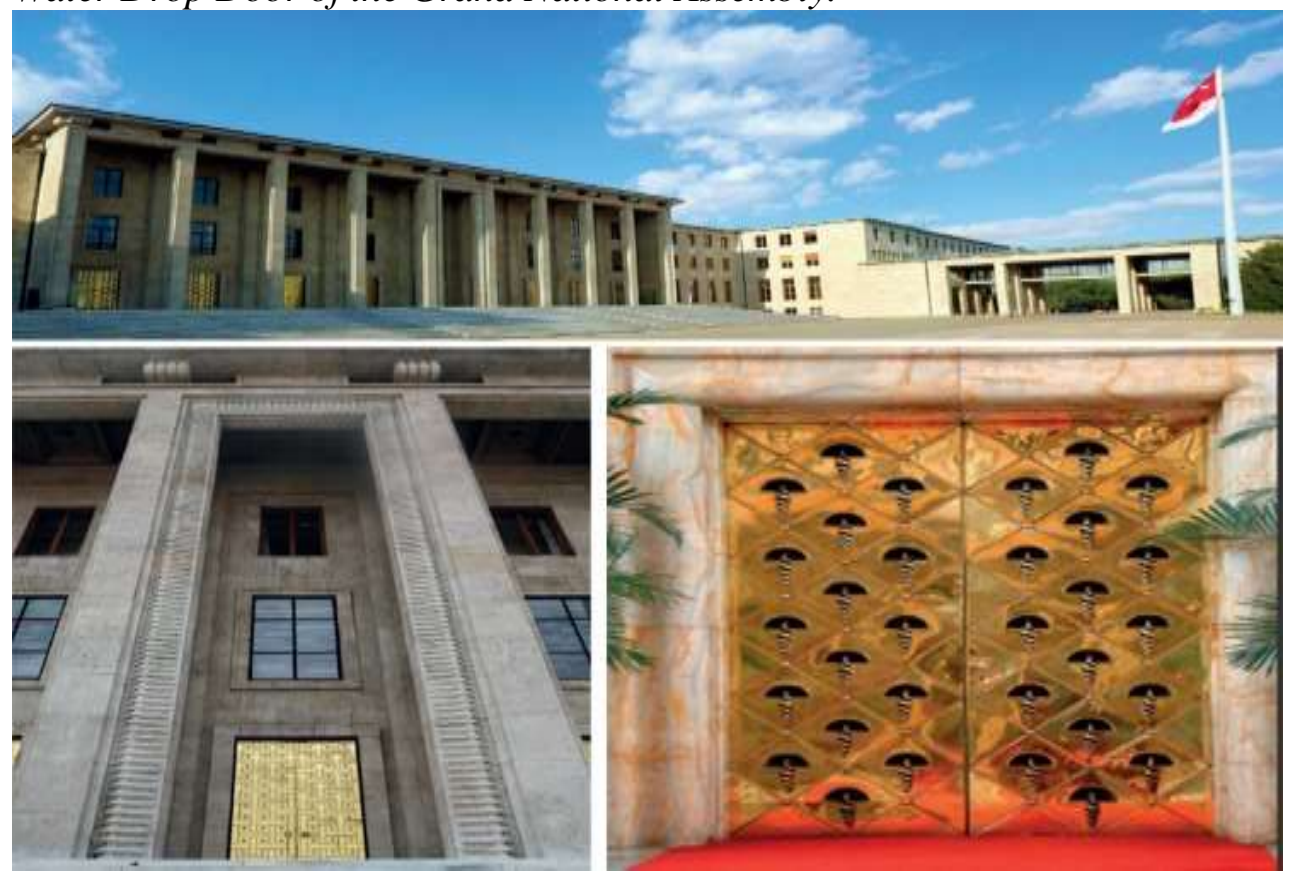

Source: Buildings of the Grand National Assembly of Turkey, 20, 25, 27. 
As a continuation of the symbolic representations of the long-lived existence of the Turkish states, sixteen crystal chandeliers (Figure 6) illuminate the general convention hall (Yartm Astrlık Meclis Binası: 51. Yll, 2012). In addition to the object-scale and ornamental details in the GNAT, the material selections are made of Afyon marbles to declare and propagate the local wealth of the country in construction materials. Importantly, as another significant symbols, the figures of anther and leo are higly used in the campus to symbolize agricultural activity of Turkey and the power symbol used from the times of the Hittites in Anatolia (Yarım Asırlık Meclis Binası: 51. Yll, 2012).

Figure 6. The Chandeliers of the General Hall of the GNAT, Symbolically Representing the Sixteen Turkish States

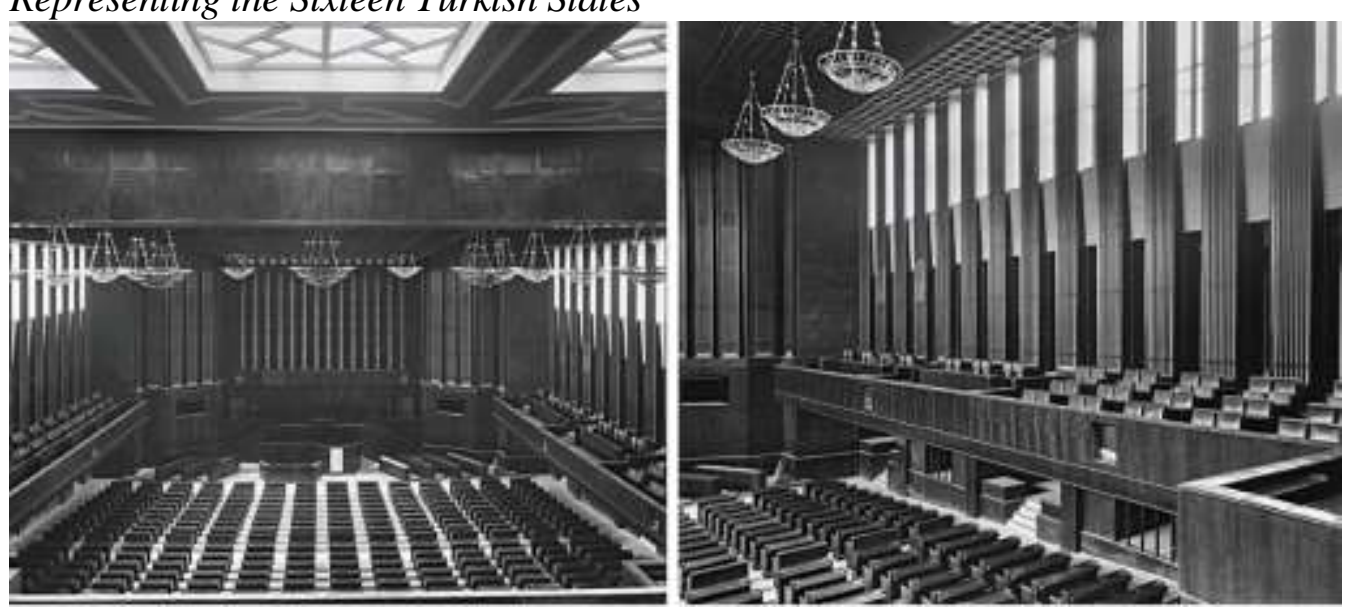

Source: Yarım Asırlık Meclis Binası: 51. Y11, 74,76.

On the one hand, the symbolic interior details representing the long history of the Turkish state date back to the Holzmeister's original project for the GNAT, the second phase of the representations of the Turkish Republic corresponds to the last years of the 1970s when, the Committee of Monuments and Buildings (Anitlar ve Yapılar Hazırlık Komitesi) held a meeting for receiving opinions to construct monuments inner and outer spaces of the assembly symbolizing the principles of Atatïrk and the Turkish national existence. In his opening speech for this meeting, the President of the Republic Senate Tekin Arıburun declared that "what is a Turkish state? How long has it been on these lands? How it has gained its democratic character? These questions are frequently discussed in the assembly, but all the spoken words fly away. There are not any trace remains from these words... Here, you are supposed to concrete these discussions physically in the assembly... The story of the Turkish nation have to be seen, read and felt in the building..." (TBMM Anıtlar Dizisi - Önfikir Araştırması I. Toplantı, Bildiriler ve Tutanaklar, 1976). In these words, Arıburun clearly expresses the iconographic role of the GNAT for the Turkish nation by placing the building as a monumental representation of the Republic. By handling newly built statues and monuments in the GNAT campus as meaningful entities, Arıburun ideologically links the existence of the assembly with the existence of the Republic. 
Moreover, Ziya Payzin, who was the chief architect of the assembly in the construction process, declares "...the Committee of Monuments and Buildings decided that the north-south axis of the assembly will be furnished with statues representing the development of the Turkish national history, and the east-west axis will be furnished with the statues of the history of Turkish principles. It has vital important to decide which themes and principles have to be represented in the GNAT. Thus, this meeting is organized and asked for help from the science and the nation" (TBMM Anıtlar Dizisi - Önfikir Araştırması I. Toplantı, Bildiriler ve Tutanaklar, 1976).

As clearly stated in the selected speeches, the GNAT was placed at the center of collective events of the Turkish nation through the physical representations of the Republic. In this way, the outdoor of the GNAT become a common stage for the nation where the ceremonies, celebrations and commemorations have regularly repeated to keep alive the memories of the Republic and the Turkish national identity (Figure 7). In a parallel vein, celebrations, ceremonies or inaugural gatherings for political periods open roads for remembering by establishing living connections between the artefacts and societies.

Figure 7. The Opening Ceremony of the GNAT in 1961

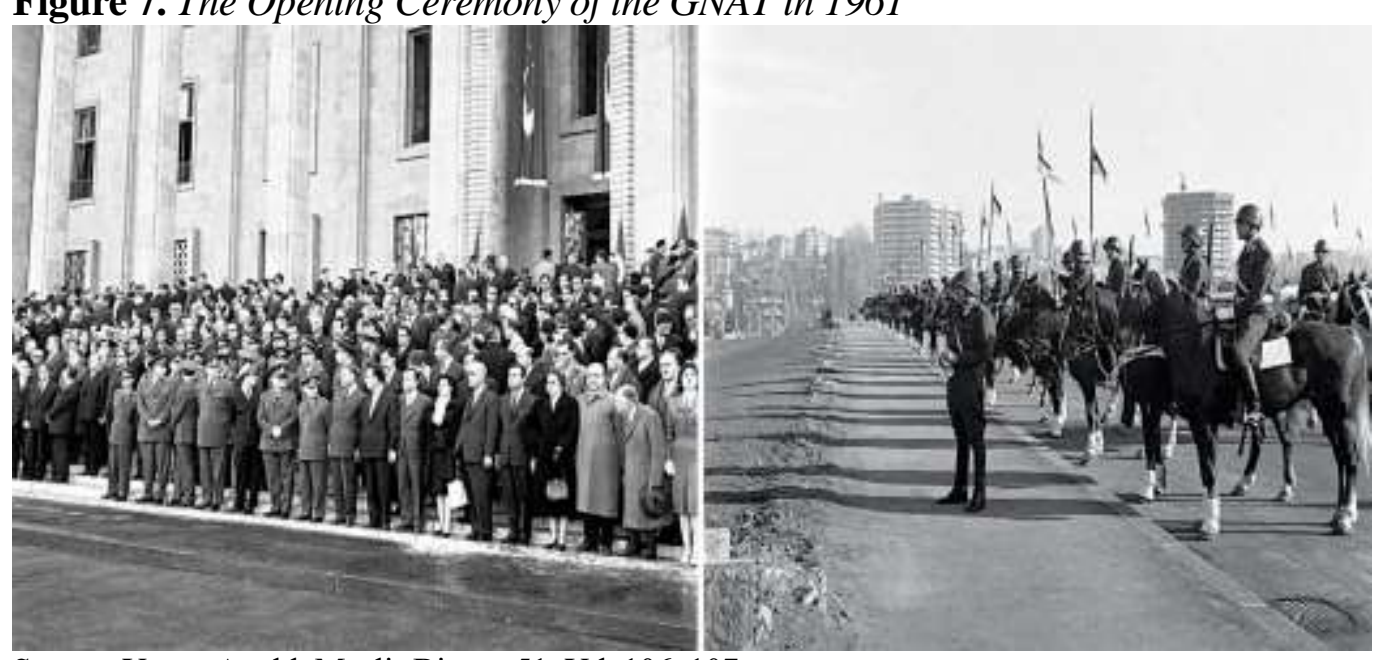

Source: Yarım Asırlık Meclis Binası: 51. Y11, 106, 107.

By specifically discussing commemorations, Jones points out the repetitive character of collective occasions which are commonly shared by people at certain times and certain places (Jones, 2007). Accordingly, on the one hand the collective rituels by itself becomes a storage for memory, on the other hand, all the actors in this process from the architectural artefact housing the ceremony to the speeches are included in material culture and discussed as memory storages of recollection for future generations.

In this respect, symbolic details discussed above have equal importance in propagating and representing the Turkish national identity in the building scale through the national celebrations of the Republic. While the ceremonial occassions have been conducting in the front square of the GNAT, the flying Turkish flag, grandiosely ornamented gates of the parliament building and the Atatürk 
Monument explicitly refer to the symbols of Turkishness from the history onwards. In this respect, the construction and consolidation process of the Turkish national identity is fed from the ceremonies and their symbolic agents in the building scale as the memory spaces of the Republic.

From a similar perspective, in Time and Memory, Crawford discusses commemorations as instruments to meet past and the present, remembering and forgetting (Crawford, 2005). By drawing attention of their collective occurrence, Crawford evaluates commemorations as intentional meetings where "the experiences and recollections of individuals weaved into a communal fabric" (Crawford, 2005). Importantly in Crawford's approach, commemoration operates as a tool which blurs individual boundaries in order to create a collective belonging in a society, especially based on a collectively shared historical past. Similar to Nora's approach, commemorations become the repetitions of "learned stories" in place of remembrance of a historical past (Crawford, 2005). In this way, they operate as "attractors" and starting points for planned future constructions which draw their strenghts from history itself (Crawford, 2005). Parallel with this understanding in practice, the meetings of the Committee of Monuments and Buildings (Anitlar ve Yapılar Hazırlı Komitesi) in 1976, point out a construction process of a collective ceremonial areas and landmarks in the GNAT complex to keep alive the memories of the Republic in symbolic details and monuments.

As the first initiation of the Committee was the national competition for the Atatürk Monument of the GNAT in 1978. Previously, in Holzmeister project of the GNAT, the Atatiirk Monument was proposed in detail on the roof of the front facade of the parliament building (Figure 8). However, as Demirkol states, this proposal contradicted with the ideological mindset of the Republic, which aims to connect the administrative leaders to the nation democratically and equally. Thus, "the founder of the Republic have to be represented as a civilian but not as a commander." Holzmeister's proposal was not applied and a new competition was held (Demirkol, 2009).

Figure 8. Holzmeister's Proposal for the Atatürk Monument on the Roof of the Front Facade of the Grand National Assembly

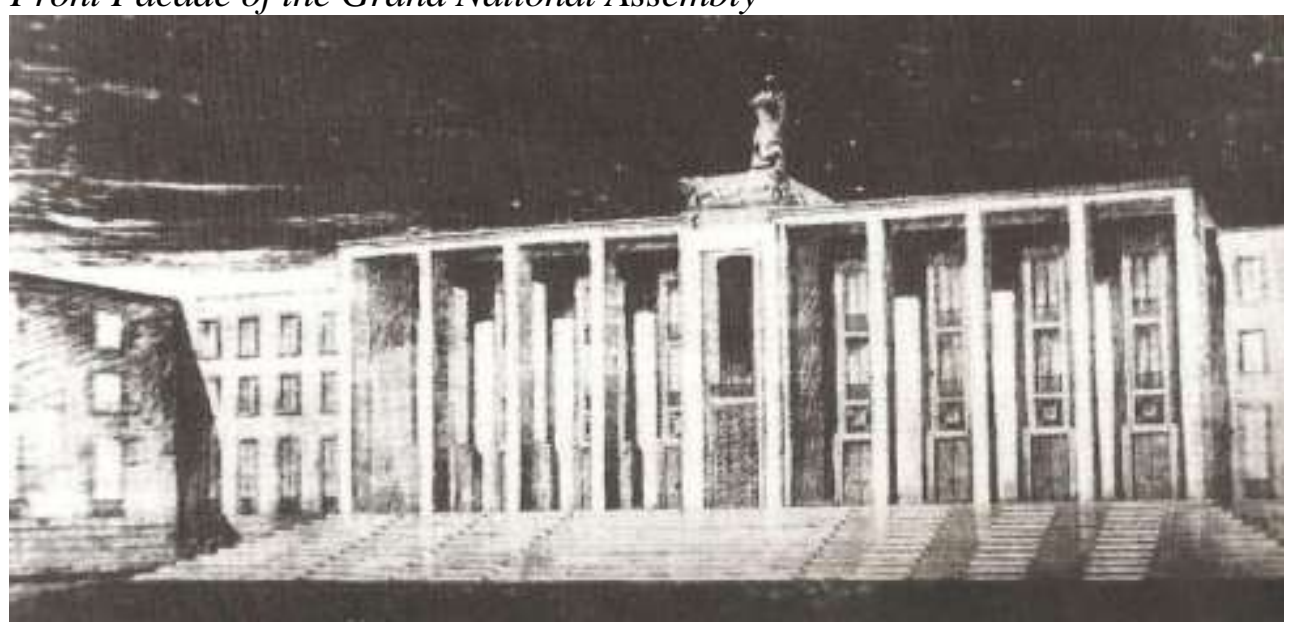

Source: Demirkol, “A Reading on Atatürk Monument in the Grand National Assembly of Turkey: From Idealized to Realized", 95. 
Amongst 43 competitors, sculptor Hüseyin Gezer and architect İmran Gezer's monument proposal was selected (Figure 9). In the report of the winning proposal, Gezer states that "we are primarily supposed to design a monument with its surrounding landscape area which allows to organize public meetings and ceremonies. Thus, in order to properly represent Atatürk and to conduct collective events, we proposed an integral project with an amphi and a circular platform located in front of the parliament building... The surrounding facades are desgined to narrate Atatürk in reliefs and inscriptions... In this way, the Atatürk Epic is expressed on wide surfaces while composing a ceremonial area in the middle of the biographical narratives... At the end of the relief and inscription compositions, the Atatürk Monument locates as an ending point by symbolizing the well-known words of Atatürk, freedom and independence is my character..." (Arkitekt, 1979).

Figure 9. Holzmeister's Proposal for the Atatürk Monument on the Roof of the Front Facade of the Grand National Assembly

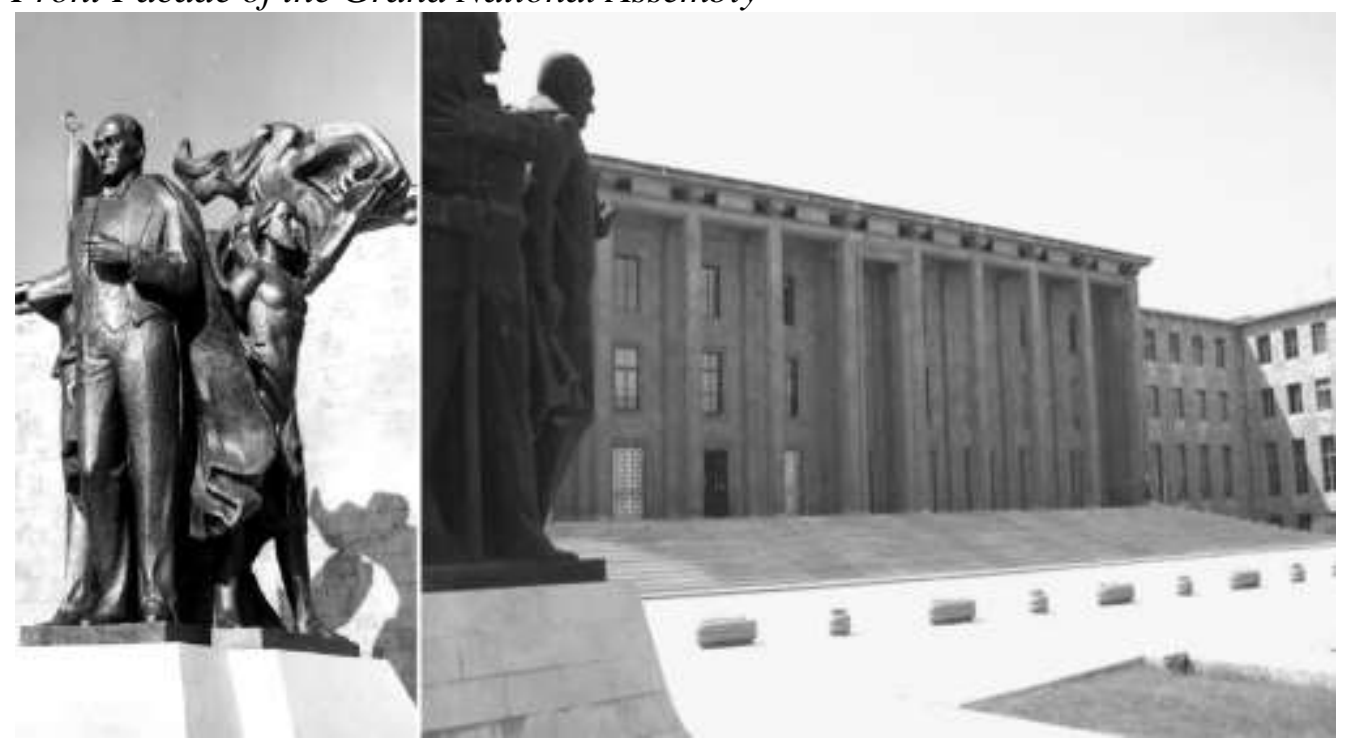

Source: Demirkol, The Turkish Grand National Assembly Complex: An Evaluation of the Function and Meaning of Parliamentary Spaces, 115.

In 1981, the opening of the Atatürk Monument was held with a well-attended public ceremony as it was supposed in the competition text (Figure 10 \& 11). Then, the monument and its square become one of the most important ceremonial area by housing the national bariam celebrations in keeping the memories of the Republic. In addition to the concrete representation of the Republic in the GNAT via structural and architectural details, the written and visual media have actively participated to keep memories of the Republic in daily circulation through photographs and news in periodicals. In Media and Memory, Garde-Hansen discusses the representation of history through images, texts and narratives as tools of "media." Accordingly, Garde-Hansen handles media as "the first draft of history" which connects historical events to the contemporary lives through the instruments of representation and points out that media become a powerful tool by including all kind of visual material evidence to declare hegemony of a society 
through national connotations (Garde-Hansen, 2011). Similarly, the power of media was also used by the state of the time and the sod-turning ceremony of the GNAT in 1939, the opening of the complex in 1961 and the first meeting of the new Republic in the parliament forcefully announced in newspapers to imprint the GNAT on memories as the iconographic representation of the Turkish national identity.

Figure 10. The Opening Ceremony of Atatürk Monument in the Grand National Assembly of Turkey in 1981.

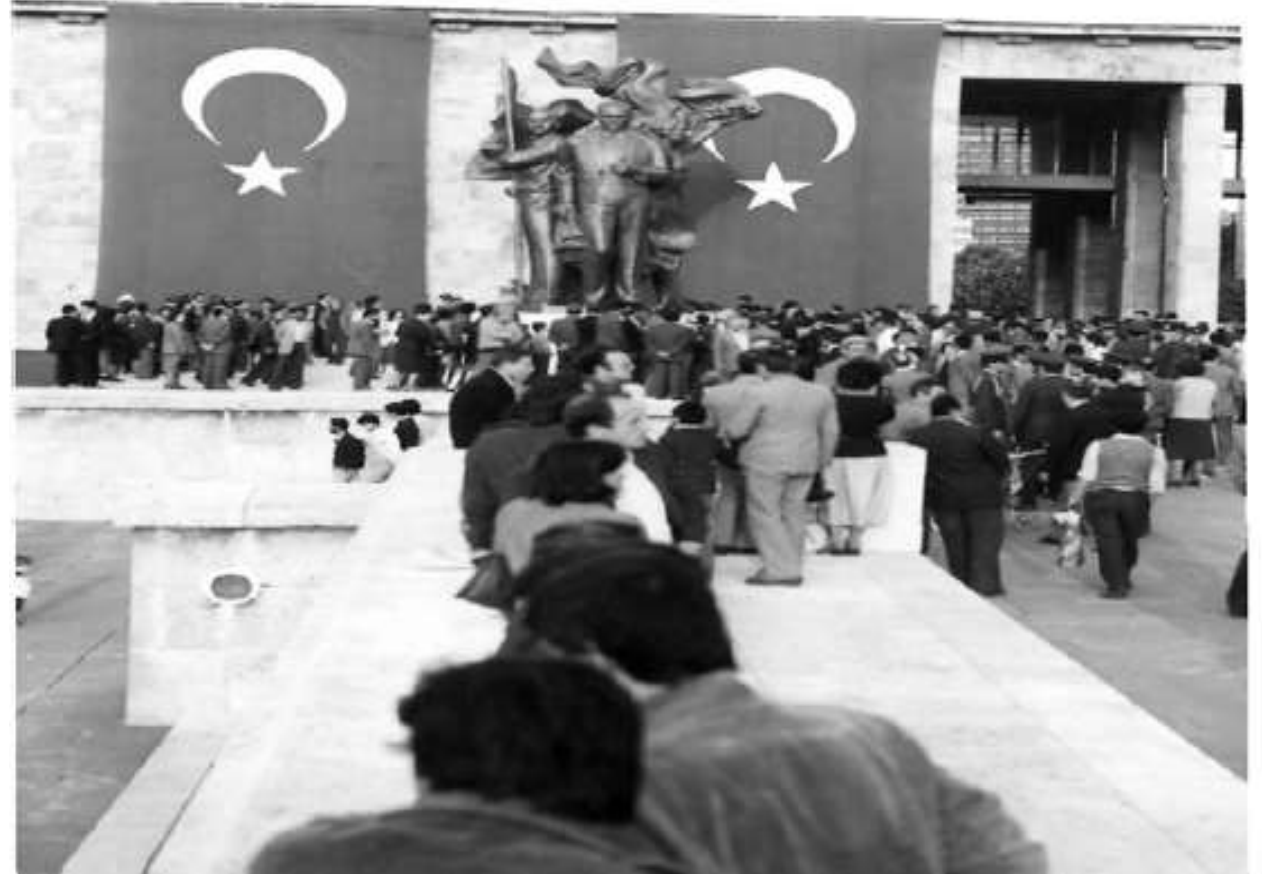

Source: Demirkol, "A Reading on Atatürk Monument in the Grand National Assembly of Turkey: From Idealized to Realized", 99.

Figure 11. The Newspaper Headlines on the Sud-turning and Opening Ceremonies of the GNAT

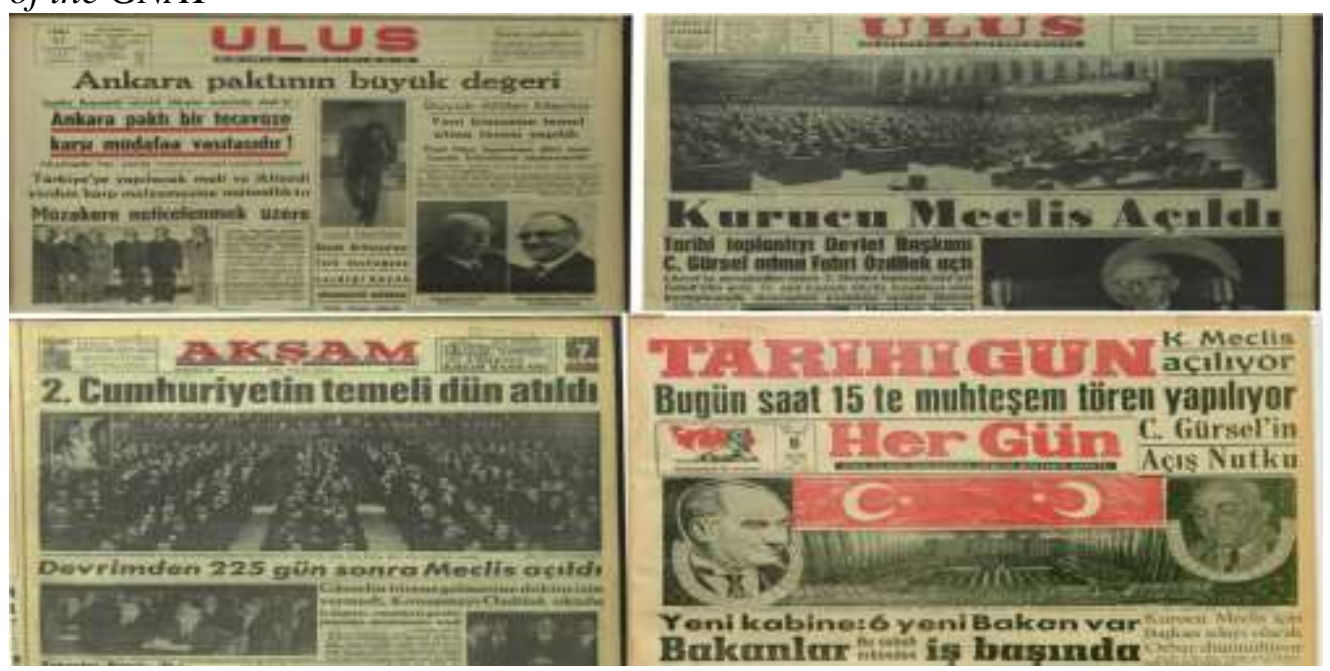

Source: National Library of Turkey, Periodicals Archive. 


\section{Conclusion}

Clearly, the Grand National Assembly of Turkey carries special meanings and symbolic representations of the country where the Anatolian lands were transformed into a homeland for Turkish nation. Both in abstract and concrete symbols, the administrative core of the country become the durable and stable icon of the long-lived existence of the Turkish nation from the centuries old history. As a brief reminder, Nora points out that the architectural artefacts may transform into laboratories for certain social, political or ideological objectives of states. In a similar way, the Early Republican Period of Turkey have also these memory spaces for constructing and declaring the comprehensive transformation of the country towards democracy from the beginning of the last century.

As briefly discussed, the national architecture movements in the first half of the $20^{\text {th }}$ century and the search for a new architectural language for the Turkish Republic are amongst significant mediators for the state to construct concrete links between the new democratic citizens and their spaces to live in. Naturally, Ankara becomes the prominent showcase of the Republic as the capital with the new city planning proposals, accommodation and working zones, and recreation areas in neighborhoods and state buildings in the Ministries Quarter.

On the one hand, these new proposals and applications in the urban structure can be classified as larger-scale representations of the Republic in planning decisions of the capital; on the other hand, each architectural construction in these proposals have various symbols and remarks of the new national architectural language of the country. Moreover, not only the Grand National Assembly but also in a large number of components in the built environment of Ankara has kept the memories of the Republic and the long-lived existence of Turkish states in history today.

Importantly, the public character of the Grand National Assembly is worthy to discuss considering the public use of the complex in special events. Although the large courtyards and gardens of the campus were planned as living spaces of the national celebrations with the participation of public, most of the time, these areas became stages for only political figures in special times, especially for the opening celebrations of the political periods. Generally, the public aspect of the complex supported by the help of the written and visual media with publishing the inner space photographs of the general meetings in party halls.

From this point of view, the Grand National Assembly of Turkey left remarks on the memories of the Turkish nation in various scales. To make it clear, the public use of the complex was underlined especially with the photographs of the interior space of the building, administrative figures, leaders and moments in political meetings and ceremonies via the printed media in daily life circulation. On the other hand, the outer spaces of the building were actively used in certain public events such as the sod-tuning ceremony of the complex in 1930s and the opening ceremony of the Atatürk Monument in 1980s.

In this way, the Grand National Assembly becomes an important part of the Turkish national identity construction period with its monumental representation and the symbolic value in the memories from the early years of the $20^{\text {th }}$ century. 
From its architectural competition text full of national connotations, to the construction details proper to the Second National Architectural Movement and to the monumental symbols in the inner and outer spaces of the campus, the Grand National Assembly of Turkey has been staying in use as the living witness and memory space of the Turkish Republic from its opening in 1961 until today in various scales of representation.

\section{References}

Arkitekt. (1979) "Türkiye Büyük Millet Meclisi Atatürk Anıtı" (originally published in Turkish - "The Atatürk Monument of the Grand National Assembly").

Aslanoğlu, İ. (2010) Erken Cumhuriyet Dönemi Mimarlı̆̆ı. (originally published in Turkish - Early Republican Architecture: 1923-1938). İstanbul: Bilge Kültuir Sanat.

Bastea, E. ed. by. (2004) Memory and Architecture. Mexico: New Mexico Press.

Bozdoğan, S. (2012) Translated by Tuncay Birkan. Modernizm ve Ulusun Inşası (originally published in English - Modernism and Nation Building: Turkish Architectural Culture in the Early Republic, 2001). İstanbul: Metis Yayınlar1.

Cengizkan, A. (2010) "Holzmeister, et al. A Mise en Scene for Republican Power: Representations in the Ministries Quarter, Ankara." In Clemens Holzmeister: An Architect at the Turn of the Era. İstanbul: Boyut Yayınc1lik.

Cengizkan, A. "Türkiye için Modern ve Planlı Bir Başkent Kurmak: Ankara 1920-1950." (originally published in Turkish - "Construction of a Modern and Planned Capital for Turkey: Ankara 1920-1950") Available from: http://www.goethe.de [Accessed: 9.3.2018]

Crawford, M. (2005) "Commemoration: Where Remembering and Forgetting Meet", in Time and Memory (ed. by Paul Harris et. al.).

Demirkol, H. G. (2009) "The Turkish Grand National Assembly Complex: An Evaluation of theFunction and Meaning of Parliamentary Spaces," Ph.D. dissertation. Ankara: Middle East Technical University.

Ergut, T. E. (1998) "Making a National Architecture: Architecture and the Nation-state in EarlyRepublican Turkey, Ph.D. dissertation. Ankara: Middle East Technical University.

Feroz, A. (1993) The Making of Modern Turkey. New York: Routledge Taylor \& Francis Group.

Garde-Hansen, J. (2011) Media and Memory. Edinburgh: Edinburgh University Press.

Halbwachs, M. (1992) On Collective Memory (trans. and ed. by Lewis A. Coser). Chicago: University of Chicago Press.

Jones, A. (2007) Memory and Material Culture. Cambridge: Cambridge University Press. Kadıŏlu, A. (1997) "Cumhuriyetin Kuruluş Yıllarında Türk Milliyetçiliğinin Çelişkisi ve

SeçkinlerinTavrı." ("The Paradox in Turkish Nationalism in the Founding Years of the Republic and the Republican Elite"). In Cumhuriyet, Demokrasi ve Kimlik Seтроzуuти Kitabı, Ankara: Bağlam.

Lowenthal, D. (2005) Past is a Foreign Country. Cambridge: Cambridge University Press.

Nora, P. Hafiza Mekanlart. (2006) Translated by Mehmet Emin Özcan (originally published in French, Les Lieux de Memoire, 1984). Ankara: Dost Kitabevi Yayınları.

Sözen, M. (1996) Cumhuriyet Dönemi Türk Mimarisi (originally published in Turkish Turkish Architecture in the Republican Period). İstanbul: Türkiye İş Bankası Yayınları. 
Vol. 5, No. $1 \quad$ Taraz \& Yllmaz: The Grand National Assembly of Turkey and its...

TBMM Anıtlar Dizisi - Önfikir Araştırması I. Toplant, Bildiriler ve Tutanaklar (1976) (originally published in Turkish - GNAT Monuments Series: The First Meeting of the Opinion Survey, Reports and Proceedings). Ankara: TBMM Matbaas1.

TBMM Kampüsünün Dünü-Bugünü-Yarını (1976) (originally published in Turkish - The Past-Present-Future of the GNAT Campus). Ankara: Türkiye Büyük Millet Meclisi Matbaasi.

Tümer, G. (1998) Cumhuriyet Dönemi'nde Yabancı Mimarlar Sorunu (originally published in Turkish - The Foreign Architects Issue in the Republican Period). İzmir: İzmir Mimarlar Odası Şubesi).

Vale, L. (2008) Architecture, Power, and National Identity. London: Routledge Taylor \& Francis Group.

Yartm Asırlık Meclis Binasl: 51. Yll (originally published in Turkish - Half-Century Old Assembly Building: 51st Year). Ankara: TBMM Prestij Kitaplar, TBMM Basın, Yayın ve Halkla İlişkiler Başkanlı̆̆ Yayınları No:1, Nisan 2012.

www.tbmm.gov.tr [Accessed: 11.3.2018]

www.kultur.gov.tr [Accessed: 11.3.2018] 